\title{
Tax Reform and Trade Openness in Developing Countries
}

\author{
SENA KIMM GNANGNON ${ }^{1+}$ \\ ${ }^{1}$ World Trade Organization, Geneva, Switzerland
}

\begin{abstract}
Developing countries are confronted with the progressive erosion of their trade tax revenue, which then reduces their total tax revenue. In light of the unavoidable process of trade liberalization, such countries have engaged in tax transition reform to change their tax revenue structure in favor of domestic tax revenue. The current analysis uses a measure of tax transition reform (tax reform) to examine whether countries that engage in tax reform experience greater trade openness. The empirical analysis covers 92 developing countries from 1980 to 2014 and shows that tax reform is positively associated with trade openness. Interestingly, least developed countries (LDCs) appear to enjoy a higher effect of tax reform on trade openness than non-LDCs do. This is confirmed by a more general picture that shows how less advanced developing countries enjoy a higher positive effect of tax reform on trade openness than relatively advanced developing countries do.
\end{abstract}

Keywords: Tax transition reform, Trade openness, Developing countries

JEL Classifications: F02, F15, O11, I32

Received 14 July 2019, Revised 7 August 2019, Accepted 14 August 2019

\section{Introduction}

International trade tax revenue still represents an important share of a country's total public revenue. Thus, one reason underlying the adoption of restrictive trade policy measures by policymakers in developing countries is the fear of losing this revenue because of greater trade openness or the liberalization of trade regimes. In fact, several studies have reported evidence of the negative effect of trade liberalization on tax revenue (e.g., Cagé and Gadenne 2018, Hisali 2012, Khattry and Rao 2002). The potential tax revenue losses associated with greater trade liberalization (or trade openness) has led international financial institutions, such as the International Monetary Fund (IMF) and the World Bank, to advise policymakers of developing countries to undertake a tax reform (or "tax transition reform") (e.g., Chambas 2005, Keen

\footnotetext{
+Comesponding Author: SENA KIMM GNANGNON

Economic Affairs Officer, World Trade Organization (WTO), Rue de Lausanne 154, CH-1211, Geneva 21, Switzerland. Email: kgnangnon@yahoo.fr
}

Acknowledgements: This article represents the personal opinions of individual staff members of the WTO and is not meant to represent the position or opinions of the WTO or its Members, nor the official position of any staff members. The Author would like to express his sincere gratitude to the Reviewer and the Editor for their useful comments on the previous version of article. Any errors or omissions are the fault of the author. 
2012). This reform is expected to transform the structure of the tax revenue in these countries from its current high dependence on international trade tax revenue to a greater dependence on domestic tax revenue. Such a tax reform would ultimately lead to a tax structure in developing countries that is similar to the one in developed countries (industrialized nations), where the trade tax revenue is far lower than the domestic tax revenue (Tanzi 1992, Zee 1996, Tanzi and Zee 2000).

The policy advice of the international financial institutions rests on the idea of a tariff-tax reform involving a one-unit reduction in tariff and, concomitantly, a one-unit increase in the consumption tax. As noted by Keen and Ligthart (2002), this proportional tariff-tax reform does not affect consumer prices, but does affect the production sector of the economy. Thus, a reduction of implicit production subsidies (due to declining tariffs) would allow efficient allocation of resources in the production sector, generate welfare gains, and also increase public revenue. The literature on the tariff-tax reform has usually investigated the effect of tariff-tax reform on market access, public revenue, and welfare (e.g., Fujiwara 2013, Hatzipanayotou et al. 1994, Keen and Ligthart 2002, 2005, Kreickemeier and Raimondos-Møller 2008, Karakosta and Tsakiris 2014). Specifically, the literature on the effect of tariff-tax reform on market access (defined as the value of import volumes at the world price) has usually focused on one specific tariff-tax reform that involves a one-unit tariff reduction and an increase in consumption tax by one unit, as advised by international financial institutions. Hatzipanayotou et al. (1994) showed that this policy reform is welfare-improving for a competitive, small economy. Whereas Keen and Ligthart (2002) generalized this result, they later demonstrated that, in the context of imperfect competition, this result no longer holds (Keen and Ligthart 2005). Kreickemeier and Raimondos-Møller (2008) theoretically proposed that point-by-point policy reform might not increase market access, although it may improve welfare and increase revenue. Fujiwara (2013) theoretically proved that, under decreasing marginal costs, point-by-point policy reform improves market access, welfare, and public revenue.

The current analysis aims to examine the effect of tax reform on trade openness in developing countries. Compared with previous studies on the market access effect of tariff-tax reform, which we highlighted above, the novelty of the current study is twofold. First, it relies on an indicator that captures tax (transition) reform, as defined above, and which is constructed based on the semi-metric Bray-Curtis dissimilarity index (Bray and Curtis 1957). This indicator captures the degree of convergence of a developing country's tax structure toward the tax structure of developed countries. Second, we focus on trade openness and not on market access, although both concepts are interrelated. Thus, to the best of our knowledge, this is the first study on the effect of tax reform on trade openness.

The empirical analysis is conducted using a panel dataset of 92 countries and spans the 1980 2014 period. It shows that tax reform induces greater trade openness. This positive effect 
is dependent on the income level of countries (a proxy for their development level), as, among developing countries, less developing ones experience a higher positive effect of tax reform on trade openness than relatively advanced developing countries do.

The remainder of the article is organized as follows: Section 2 presents the indicator of tax reform used in the analysis, whereas section 3 discusses the measure of trade openness. Section 4 discusses how tax reform could influence trade openness. Section 5 presents the model specification that helps address the subject of this article and discusses the appropriate econometric estimator to conduct the empirical analysis. Section 6 presents empirical results, and section 7 concludes the paper.

\section{Measure of the Extent of Tax Reform}

Following Gnangnon and Brun (2019b), the extent of tax reform is measured by relying on the semi-metric Bray-Curtis dissimilarity index (Bray and Curtis 1957). This index allows us to compare the tax structure of a given developing country to the tax structure of developed countries. It captures the degree of convergence of a developing country's tax structure toward the tax structure of developed countries (qualified as "old industrialized countries"). It is worth noting that the Bray-Curtis index has been used before in natural sciences and social sciences such as international trade (e.g., Finger and Kreinin 1979, De Benedictis and Tajoli 2007, 2008).

The formula of the Bray-Curtis index applied to the tax structure is as follows:

$$
d_{i t}=\frac{\mid \text { DIRTAX }_{i t}-\text { DIRTAXAve }_{t}|+| \text { INDIRTAX }_{i t}-\text { INDIRTAXAve }_{t} \mid}{+\mid \text { IRTAX }_{i t}-\text { TRTAXAve }_{t} \mid}
$$

where DIRTAX, INDIRTAX, and TRTAX are, for a given developing country, the ratio of direct tax revenue in its GDP, ratio of indirect tax revenue in its GDP, and ratio of trade tax revenue in its GDP, respectively. DIRTAXAve, INDIRTAXAve, and TRTAXAve are, for developed countries, the average (over all developed countries, in a given year) of the direct tax revenue to GDP ratio, indirect tax revenue to GDP ratio, and international trade tax revenue to GDP ratio, respectively. Natural resource revenue is excluded from all tax revenue variables to capture a more homogenous indicator of tax reform. In fact, many countries are dependent on natural resources for their tax revenue; including natural resource revenue in the abovementioned tax revenue variables would thus generate a misleading indicator of tax reform. It might even lead to erroneous empirical outcomes and policy conclusions.

The index of tax reform (denoted "TAXREF") is then calculated as follows: TAXREF= 
$\left(1-d_{i t}\right) * 100$, where $d_{i t}$ is the Bray-Curtis dissimilarity index obtained from formula (1). For a given country in a given year, this index reflects whether the country's tax structure is converging toward (or diverging from) the tax structure of developed countries. The values of this index range between 0 and 100. Higher values indicate a greater extent of tax reform, that is, a convergence of the tax structure of a given developing country toward that of developed countries. Inversely, declining values of this index indicate a lower extent of tax reform, that is, a divergence between the tax structure of a given developing country and of developed countries. We provide in Appendix 1 the list of developed countries that are used as a benchmark to compute the index of tax reform.

As observed by Gnangnon and Brun (2019b), the above index has been computed using tax revenue variables, which themselves depend on countries' structural factors, such as the development level, population size, structure of output, degree of trade openness, and institutional quality (e.g., Baunsgaard and Keen 2010, Crivelli 2016, Gnangnon and Brun 2017, Khattry and Rao 2002). Thus, it could be considered a de facto measure of tax reform and not a de jure measure, which would better reflect policymakers' decisions concerning the implementation of tax reform. Nevertheless, by controlling for many of these structural factors in the model specification, we could uncover the genuine effect of tax reform, thus reflecting the policymakers' decision on the degree of trade openness.

\section{Measure of Trade Openness}

In the literature, trade openness has sometimes been used interchangeably with trade policy. However, these two variables reflect different realities 1 ). Trade openness is an outcome of several factors, including social, cultural, geographical, and economic factors (which, in turn, include trade, exchange rate, financial, and other policies) as well as international politics (driven by interest groups), which governments cannot control. Therefore, it represents a de facto measure of openness to international trade. Trade policy reflects the policymakers' decision to open an economy to international trade. Therefore, it represents a de jure measure of openness to international trade. In this respect, de facto measures of trade openness contain more exogeneous elements than de jure measures (also a similar reasoning by Baltagi et al. [2009] for the case of financial openness). For example, de jure measures of trade openness include incidence-based indicators, such as the average level of tariffs, percentage of imports subject to nontariff restrictions, level of export taxes, a combination of these partial trade policy instruments (e.g., the Sachs and Warner's [1995] indicator, which is a dummy variable capturing trade liberalization),

1) See Gräbner et al. (2018) for a recent literature review on the measure of trade openness. 
a measure of "residual openness,"2) "freedom to trade internationally" 3 ) indicator, and the de jure index of trade globalization, which is a weighted index of trade regulations, trade taxes, tariffs, and trade agreements (see Dreher 2006, Gygli et al. 2019).

As noted above, de facto measures of trade openness are outcome indicators. They include, for example, price-based indicators such as the Dollar-type index ${ }^{4)}$ (Dollar 1992) as well as quantity-based indicators such as the trade share (i.e., the ratio of exports plus imports of goods and services in percentage of GDP), which is widely used in the empirical literature. Quantity-based indicators also include the de facto index of trade globalization, which is a weighted index of trade in goods as well as in services and partner diversity (see Dreher 2006 and Gygli et al. 2019). More recently, Squalli and Wilson (2011) highlighted the limits of the traditional measure of trade openness (i.e., the trade share) and proposed another de facto trade openness indicator, calculated as the trade share indicator adjusted by the proportion of a country's trade level relative to the average world trade (see Squalli and Wilson 2011, p. 1758). This indicator has an advantage of providing good indication of a country's level of integration into the global trade market. We primarily use the indicator proposed by Squalli and Wilson (2011). For the robustness check, we use the standard trade openness measure (i.e., the ratio of exports plus imports of goods and services in percentage of GDP).

\section{Discussion on the Effect of Tax Reform on Trade Openness}

From a theoretical perspective, we argue that any tax reform would mainly affect trade openness through its effect on public revenue, notably tax revenue. In that respect, we could expect that, by inducing higher tax revenue, tax reform would generate higher trade openness (hypothesis 1). However, if tax reform is associated with lower tax revenue (because countries are not able to raise domestic tax revenue to at least compensate for the trade tax revenue losses arising from greater trade openness), then it would be associated with lower level of

2) The residual openness index is calculated using a regression of the trade share on the non-policy determinants of trade flows (demographic and geographic factors) to separate "natural openness" (i.e., fitted value of the regression) from "residual openness" (the residual of the regression, which reflects the "man-made choices" shaping a country's trade openness) (e.g., Combes and Saadi-Sedik 2006, Esfahani and Squire 2007).

3) This is a is a key component of the Economic freedom Index. There are two types of this indicator: one is proposed by the Heritage Foundation with data starting from 1995 onward (for further information, see online at: https://www.heritage.org/index/explore) and another, which is closely related to the previous one, is developed by the Fraser Institute, and covers the period from 1970 onward. Data for this indicator from 1970 to 1999 are provided every five years and data from 2000 are provided annually (for further information, see online at: https://www.fraserinstitute.org/economic-freedom/dataset?geozone=world\&year=2016\&page=dataset\&min-year=2 $\&$ max-year $=0 \&$ filter $=0$ ).

4) The Dollar-type index is calculated as the ratio of the actual real exchange rate relative to its predicted value based on the regression of the real exchange rate on its nonpolicy determinants. 
trade openness (hypothesis 2). We discuss, in turn, each of these hypotheses.

Concerning hypothesis 1 , we argue that, if tax reform allows developing countries to recoup more than the trade tax revenue losses (by substantially increase domestic revenue) and increase their total tax revenue, then policymakers might not fear opening up their economies to international trade. The rise in public revenue would help them promote international trade through investment in all factors that contribute to enhancing international trade flows, notably infrastructure, human capital, and institutional quality (conducive business environment). In this context, tax reform would be associated with greater trade openness.

Recent studies (Baunsgaard and Keen 2010, Crivelli 2016, Moller 2016, and Waglé 2011) have explored whether developing countries have recouped the trade tax revenue losses induced by trade liberalization from other sources, including domestic tax revenue. They report that countries endeavor to recoup the lost trade tax revenue by increasing the domestic tax revenue. For example, Baunsgaard and Keen (2010) provided empirical evidence to show that the replacement rate is low for low-income countries even though the signs of recovery vary across countries. However, middle- and high-income countries have been able to recoup the lost trade tax revenue from other sources. Waglé (2011) found that the tax recovery in low-income countries is much more robust than that shown by Baunsgaard and Keen (2010), although long term replacement is statistically significant only for a few countries. In the same vein, Moller (2016) revealed that low-income countries that have simultaneously initiated a process of democratization are those that have enjoyed a significant tax recovery. Crivelli (2016) provided empirical evidence to show that, for transition economies in Eastern Europe, the former Soviet Union, North Africa, and the Middle East, there is strong revenue replacement of lost trade tax revenue with total domestic tax revenue, notably through the value-added tax and personal income tax.

In addition to its indirect effect on trade openness through tax revenue, tax reform could also influence trade openness through its effect on trade policy. In fact, policymakers should further open up their trade regimes to ensure countries can collect higher domestic tax revenue during the tax reform process. This is because higher value addition to domestic production is an important determinant of tax revenue (e.g., Baunsgaard and Keen 2010, Crivelli 2016, Gnangnon and Brun 2017, Khattry and Rao 2002). Further, trade policy liberalization is essential to encourage domestic firms to add value to their production by reducing their production costs, notably the costs of imported intermediate inputs used in their production process. Hence, greater trade policy (de jure trade policy) liberalization during the tax transition reform process could lead to greater de facto trade openness. Along this line, studies have reported a positive effect of trade liberalization on exports (e.g., Ahmed 2000, Bleaney 1999, Santos-Paulino 2002a, Ju et al. 2010, Zakaria 2014) and imports (e.g., Bertola and Faini 1991, Ju et al. 2010, Santos-Paulino 2002b, Santos-Paulino 2004, Santos-Paulino and Thirlwall 2004, Zakaria 2014), which could 
suggest a positive effect on trade openness (as defined above).

As for the second hypothesis, countries (for example, very poor countries) could lack the capacity-including human resources in the tax and revenue administrations - to effectively design the tax reform (tax policy as well as tax and revenue administration reforms) that would help undertake tax reform successfully, such as by raising the level of total tax revenue in the context of declining trade tax revenue. In this scenario, the tax reform would be negatively associated with trade openness. However, development aid could help countries that are facing difficulties in successfully undertaking the tax reform through, for example, technical assistance to help them design tax policy as well as tax and revenue administrations reforms, or by affecting the distribution of the costs and benefits of the reform. That is to say-in the latter case, by targeting groups (including firms and households) that would be adversely affected by the implementation of the reform. (e.g., Attila et al. 2009, Gnangnon 2019a). In this specific case, tax reform would be associated with greater trade openness.

\section{Empirical Analysis}

This section presents the model specification that would help empirically test the effect of tax reform on trade openness. It then discusses the econometric estimator to estimate this model.

\section{A. Model specification}

To empirically examine the effect of tax reform on trade openness, we draw on certain extant studies (e.g., Fukumoto and Kinugasa 2017, Goswami 2013, Guttmann and Richards 2006) on the determinants of trade openness5) (i.e., de facto trade openness). In addition to the main variable of interest, which is the de facto measure of trade openness, we use control variables that could affect the effect of tax reform on trade openness. These control variables include a de jure trade openness indicator (trade policy) (“TRJURE"); development aid flows (“NAT"); real per capita income (“GDPC"), which captures countries' development level; depth of financial development ("FINDEV"); institutional quality proxied by the democratization level of countries ("POLITY2"); current account balance ("CAGDP"); inflation rate (whose transformation is denoted "INFL"; see Appendix 1); and countries' size, measured by the population size ("POP").

We expect restrictive trade policies to result in lower import flows. Restrictive trade measures would also adversely affect export flows if they increase the costs of intermediate inputs used by exporting firms in their production processes of exportable goods and services. Likewise,

5) It is worth highlighting that, in their respective studies, Milner and Kutoba (2005) as well as Svaleryd and Vlachos (2002) have used both de jure and de facto measures of trade openness in their analysis. 
we expect a rise in the development level to result in lower barriers to trade (e.g., Easterly and Rebelo 1993, Rodrik 1995, Svaleryd and Vlachos 2002, Milner and Kutoba 2005), and hence induce greater trade openness. At the same time, an increase in the population size could lead governments to adopt restrict trade policies (e.g., Rodrik 1997) to encourage production for the domestic market at the expense of international trade. This would result in lower trade openness. However, countries characterized by an important share of the working-age population would experience greater trade openness (e.g., Fukumoto and Kinugasa 2017).

Let us consider the effect of development aid flows on trade openness. Development aid could induce the Dutch Disease effect (i.e., an appreciation of the real effective exchange rate) by shifting resources from the tradable sector to the non-tradable sector, thereby hurting recipient-countries' export competitiveness (e.g., Collier 2007, Munemo 2011) and lowering their exports. At the same time, such appreciation of the real effective exchange rate would result in higher imports. In this context, the combined effect of development aid flows on trade openness through the Dutch Disease effect is a priori unknown, given that trade openness includes the sum of exports and imports of goods and services. Part of this aid could also be used by recipient-countries to further liberalize their trade regimes (this was the case in the context of the structural adjustment programs; e.g., Ancharaz 2003, Borgatti 2007, La Ferrara 1996), which could contribute to greater trade openness. Part of the development aid flows called "aid for trade policy and regulation" also helps developing countries implement WTO agreements, which, through the liberalization of domestic trade regimes, could contribute to promoting trade openness. Development aid flows could also positively influence trade openness through their positive effect on human capital accumulation, including educational outcomes 6 ) (e.g., Dreher et al. 2008, Birchler and Michaelowa 2016) and health outcomes7) (Pickbourn and Ndikumana 2016, Kotsadam et al. 2018). This is because better human capital is associated with higher export performance8) (Hausmann et al. 2007, Farok and Mudambi 2008, Andersson and Johansson 2010, Agosin et al. 2012), and hence higher participation in international trade. This, turn, would lead to greater trade openness. Further, as development aid targeted to the financial sector promotes financial development (Maruta 2018) and financial development could positively influence trade openness (Svaleryd and Vlachos 2002, Kim et al. 2010), we infer that development aid for the financial sector could result in higher trade openness.

Summing up, development aid could positively or negatively influence trade openness depending on whether the aforementioned positive effects dominate its eventual negative effect on exports through the appreciation of the real exchange rate.

6) See a literature review on the subject matter in Abby and Nio-Zarazua (2016).

7) A comprehensive literature review on the effect of development aid on health outcomes could be found in Kotsadam et al. (2018).

8) This is because, in general, better quality products require quality control procedures and better technology, with both requiring better educated workers (Fafchamps 2009). 
With respect to the effect of financial development on trade openness, a number of authors have shown that countries that are financially developed and have well-functioning financial institutions (i.e., where restrictions in the credit market are low) would specialize in financially intensive goods and services, which would promote trade, particularly exports (Kletzer and Bardhan 1987, Rajan and Zingales 1998, Chaney 2005, Manova 2005). Along the same lines, Svaleryd and Vlachos (2002) argued that a developed financial system helps diversify the private sector's risks, and thus promotes trade openness. They provided empirical support for the positive effect of financial development on trade openness. In the same vein, Kim et al. (2010) empirically demonstrated that financial development exerts a positive effect on trade openness in countries that are not members of the Organisation for Economic Cooperation and Development (OECD). Incidentally, an improvement in the institutional quality is expected to enhance trade openness (e.g., Jansen and Nordås 2004, Wu et al. 2012), whereas a lower inflation rate (which reflects higher macroeconomic stability) is expected to lead to higher trade openness.

In countries that experience a deterioration of their current account, governments might be willing to promote trade, including by reducing trade barriers and implementing export promotion policies. This would drive import flows, especially if trading firms extensively use imported intermediate inputs for producing final goods. We therefore expect deterioration in the current account to be positively associated with trade openness.

Against this background, we postulate the following model (1):

$$
\begin{aligned}
\log (\text { TROPEN })_{i t}= & a_{0}+a_{1} \log (\text { TROPEN })_{i t-1}+a_{2} \log (\text { TAXREF })_{i t}+a_{3} \log (\text { TRJURE })_{i t} \\
& +\mathrm{a}_{4} \log (\text { GDPC })_{i t}+\mathrm{a}_{5} \log (N A T)_{i t}+\mathrm{a}_{6} \log (\text { FINDEV })_{i t}+\mathrm{a}_{7} I N F L_{i t} \\
& +\mathrm{a}_{8} \text { CAGDP } P_{i t}+\mathrm{a}_{9} \text { POLITY } 2_{i t}+\mathrm{a}_{10} \log (P O P)_{i t}+\mathrm{v}_{t}+\mu_{i}+\omega_{i t}
\end{aligned}
$$

where the subscript $i$ represents a given country's index, and $t$ represents the time-period. Based on available data, we construct an unbalanced panel dataset comprising 92 developing countries (which excludes countries classified by the World Bank as "High-Income Countries") spanning the period 1980 2014. We use non-overlapping five-year sub-periods of average data to smooth out the effect of business cycles on the variables. These sub-periods are 1980 1984, 1985 1989, 1990 1994, 1995 1999, 2000 2004, 2005 2009, and 2010 2014. $a_{0}$ to $a_{11}$ are the coefficients to be estimated. $\mu_{i}$ represents countries' fixed effects; $\omega_{i t}$ is an idiosyncratic error-term. $\gamma_{t}$ represent global shocks that simultaneously affect all countries' trade openness.

The descriptions and source of variables used in model (2) are provided in Appendix 1. The descriptive statistics on these variables are displayed in Appendix 2. The list of countries contained in the full sample are reported in Appendix 3.

Note that do not apply the natural logarithm to the variables CAGDP and POLITY2, because 
they contain zero values and/or negative values. The variable capturing inflation is transformed using the method proscribed by Yeyati et al. (2007) (see Appendix 1).

The dependent variable "TROPEN" represents the measure of the de facto trade openness. As noted above, it is primarily measured by the trade openness indicator proposed by Squalli and Wilson (2011), which is denoted as "OPENSW." For the robustness check, the standard measure of trade openness ("OPEN") is employed. The one-period lag of TROPEN is introduced in model (1) to capture the state-dependence nature of the trade openness variable to be persistent over time.

To obtain initial insight into the correlation pattern between tax reform and trade openness in developing countries, Figure 1 illustrates the cross-plot between each of the two measures of trade openness and our indicator of tax reform. It appears from the two graphs in this figure that tax reform is positively correlated with trade openness.

\section{B. Econometric methodology}

The dynamic nature of model (2) (as it contains the one-period lag of the dependent variable as a regressor) precludes us from using standard econometric estimators, such as the fixed effects or random effects estimators, to obtain reliable estimates. This is because, in a panel with a small time dimension and large cross-section (such as ours), the one-period lag of the dependent variable is likely correlated with the specific effects, thereby generating an endogeneity bias (the so-called Nickell bias; see Nickell 1981) when standard econometric estimators are used. Furthermore, several regressors contained in model (2) are likely endogenous, particularly due to the bidirectional causality problem. These include the trade policy indicator, development aid, financial development, institutional quality, current account, and real per capita income. To address these endogeneity concerns in the estimation of model (2), we employ the two-step system Generalized Methods of Moments (GMM) estimator (see Arellano and Bover 1995, Blundell and Bond 1998). This estimator entails the estimation of a system of equations that includes an equation in differences and an equation in levels. The lagged first differences are used as instruments for the level equation, whereas the lagged levels are used as instruments for the first-difference equation. This estimator is suitable for dynamic panels (including unbalanced panels), where the series exhibit a strong persistence over time.

Overall, our main econometric estimator is the two-step system GMM estimator. However, for the sake of comparison, we also report the outcomes of the estimation of a static version of model (2) (that is, model (2) from which we exclude the one-period lag of the dependent variable, and where the dependent variable is OPENSW). For this purpose, we use two standard estimators: the fixed effects estimator (denoted "FE-DK"), where standard errors have been corrected using the Driscoll and Kraay (1998) technique. This technique addresses heteroscedasticity, 
serial correlation, and contemporaneous cross-sectional dependence in the error term. The second estimator is the feasible generalized least squares (FGLS). The results of the estimations of the static version of model (2) using these estimators are displayed in Table 1.

The results in Table 2 are based on the estimation of model (2) as well as some variants of this model, by means of the two-step system GMM estimator. We report the outcome of the estimation of dynamic model (2) in column [1] of this table. Column [2] of the table reports the estimates arising from the estimation of dynamic model (2), where OPEN is used (for a robustness check) as the measure of trade openness. In column [3], we display the outcome of the estimation of a specification of model (2) that allows us to examine whether there is a differentiated effect of tax reform on trade openness in poor countries versus nonpoor countries. We follow the United Nations definition and consider "Least Developed Countries" (LDCs) as the poorest countries. In fact, based on several criteria, $\left.{ }^{9}\right)$ the United Nations has identified a set of countries (LDCs) qualified as the poorest and most vulnerable (in the world) to environmental and external shocks. The list of LDCs used in the analysis is provided in Appendix 3. To perform the analysis, we create a dummy variable "LDC," which takes the value 1 for LDCs and is 0 otherwise. This dummy variable is then made to interact with the TAXREF variable. Both variables are included in the model specification, which is estimated using the two-step system GMM approach. In column [4] of Table 2, we present the results of the estimation of the variant of model (2) that includes a variable capturing the interaction between the indicator of tax reform and the real per capita income. This variant would allow us to assess whether (and if so, how) the effect of tax reform on trade openness varies across countries in the full sample.

\section{Empirical Results}

The results reported in the two columns of Table 1 suggest a positive and significant effect of tax reform on trade openness, although the magnitude of the effect in the two columns are slightly different (the coefficient is 0.4 for the results based on the FE-DK estimator and 0.6 for the result based on the FGLS estimator).

We note from the control variables that the results are not necessarily similar in the two columns of Table 1. In particular, from column [1], we find that, at the $10 \%$ level of statistical significance, trade openness is positively driven by trade policy liberalization, higher real per capita income, improvement in the current account balance, lower population size, higher depth of financial development, and better institutional quality. In column [2], real per capita income,

9) These criteria as well as other information concerning the group of LDCs can be obtained online at: http://unohrlls.org/about-ldcs/ 
current account balance, a rise in the population size, and financial development are positively associated with trade openness, while development aid flows, inflation, and the institutional quality are negatively associated with trade openness. As indicated in the previous section, these results are likely biased. Therefore, we turn to Table 2, which contains the results based on the two-step system GMM estimator. First, we note that across the three columns of this table, the coefficient of the one-period lag of the dependent variable is positive and statistically significant at the $1 \%$ level. Thus, there exists persistence of the two trade openness variables

Table 1: Impact of tax reform on trade openness Estimators: FE-DK and FGLS

\begin{tabular}{|c|c|c|}
\hline & FE-DK & $\begin{array}{l}\text { FGLS with panel-specific } \\
\text { AR1 autocomelation structure }\end{array}$ \\
\hline \multirow{2}{*}{ VARIABLES } & $\log (O P E N S W)$ & $\log (O P E N S W)$ \\
\hline & (1) & (2) \\
\hline \multirow[t]{2}{*}{$\log (T A X R E F)$} & $0.404 * * *$ & $0.592 * * *$ \\
\hline & $(0.0853)$ & $(0.0683)$ \\
\hline \multirow[t]{2}{*}{$\log (T R J U R E)$} & $0.182 *$ & 0.0420 \\
\hline & $(0.104)$ & $(0.0557)$ \\
\hline \multirow[t]{2}{*}{$\log (G D P C)$} & $0.800 * * *$ & $0.995^{* * *}$ \\
\hline & $(0.0803)$ & $(0.0292)$ \\
\hline \multirow[t]{2}{*}{$\log (N A T)$} & 0.00694 & $-0.0408 * *$ \\
\hline & $(0.0143)$ & $(0.0207)$ \\
\hline \multirow[t]{2}{*}{$\log (F I N D E V)$} & $0.137 * * *$ & $0.193 * * *$ \\
\hline & $(0.0165)$ & $(0.0289)$ \\
\hline \multirow[t]{2}{*}{$I N F L$} & 0.0138 & $-0.0221^{*}$ \\
\hline & $(0.0103)$ & $(0.0123)$ \\
\hline \multirow[t]{2}{*}{$C A G D P$} & $0.00541 * *$ & $0.00340 * * *$ \\
\hline & $(0.00218)$ & $(0.000880)$ \\
\hline \multirow[t]{2}{*}{ POLITY2 } & $0.00518^{* *}$ & $-0.00784 * * *$ \\
\hline & $(0.00247)$ & $(0.00302)$ \\
\hline \multirow[t]{2}{*}{$\log (P O P)$} & $-0.433^{*}$ & $0.597 * * *$ \\
\hline & $(0.241)$ & $(0.0186)$ \\
\hline \multirow[t]{2}{*}{ Constant } & $-10.01 * * *$ & $-26.88 * * *$ \\
\hline & (3.083) & $(0.410)$ \\
\hline Observations & 405 & 399 \\
\hline Number of groups & 92 & 86 \\
\hline Within $R$-squared & 0.3802 & \\
\hline Pseudo $R$-squared & & 0.9133 \\
\hline
\end{tabular}


(OPENSW and OPEN) over time. The bottom part of Table 2 reports the results of the three tests that allows us to check the appropriateness of the two-step system GMM estimator in estimating model (1) and its variants highlighted above. These tests include the Arellano-Bond

Table 2: Impact of tax reform on trade openness Estimator: Two-step System GMM

\begin{tabular}{|c|c|c|c|c|}
\hline VARIABLES & $\begin{array}{c}\log (O P E N S W) \\
\text { (1) }\end{array}$ & $\begin{array}{c}\log (O P E N) \\
\text { (2) }\end{array}$ & $\begin{array}{c}\log (O P E N S W) \\
\text { (3) }\end{array}$ & $\begin{array}{c}\log (O P E N S W) \\
\text { (4) }\end{array}$ \\
\hline One-Period Lag of the dependent variable & $\begin{array}{l}0.617 * * * \\
(0.0209)\end{array}$ & $\begin{array}{l}0.695 * * * \\
(0.0174)\end{array}$ & $\begin{array}{c}0.656 * * * \\
(0.0259)\end{array}$ & $\begin{array}{l}0.626 * * * \\
(0.0209)\end{array}$ \\
\hline $\log (T A X R E F)$ & $\begin{array}{c}0.497 * * * \\
(0.0647)\end{array}$ & $\begin{array}{c}0.356^{* * *} \\
(0.0305)\end{array}$ & $\begin{array}{c}0.463 * * * \\
(0.0904)\end{array}$ & $\begin{array}{c}1.784 * * * \\
(0.316)\end{array}$ \\
\hline$L D C^{*}[\log (T A X R E F)]$ & & & $\begin{array}{c}0.516^{* * * *} \\
(0.101)\end{array}$ & \\
\hline$L D C$ & & & $\begin{array}{c}-1.838 * * * \\
(0.418)\end{array}$ & \\
\hline$[\log (T A X R E F)]^{*}[\log (G D P C)]$ & & & & $\begin{array}{c}-0.165 * * * \\
(0.0403)\end{array}$ \\
\hline $\log (T R J U R E)$ & $\begin{array}{c}0.173 * * * \\
(0.0437)\end{array}$ & $\begin{array}{c}0.0531 * * \\
(0.0255)\end{array}$ & $\begin{array}{l}0.283 * * * \\
(0.0426)\end{array}$ & $\begin{array}{l}0.184 * * * \\
(0.0411)\end{array}$ \\
\hline $\log (G D P C)$ & $\begin{array}{c}0.287 * * * \\
(0.0248)\end{array}$ & $\begin{array}{l}-0.00285 \\
(0.0108)\end{array}$ & $\begin{array}{l}0.258 * * * \\
(0.0507)\end{array}$ & $\begin{array}{c}0.956 * * * \\
(0.163)\end{array}$ \\
\hline $\log (N A T)$ & $\begin{array}{c}-0.0887 * * * \\
(0.0260)\end{array}$ & $\begin{array}{c}-0.0427^{* * *} \\
(0.00883)\end{array}$ & $\begin{array}{c}-0.0660 * * * \\
(0.0241)\end{array}$ & $\begin{array}{c}-0.0983 * * * \\
(0.0277)\end{array}$ \\
\hline $\log (F I N D E V)$ & $\begin{array}{l}0.116 * * * \\
(0.0201)\end{array}$ & $\begin{array}{l}0.0194 * * \\
(0.00756)\end{array}$ & $\begin{array}{c}0.0889 * * * \\
(0.0219)\end{array}$ & $\begin{array}{c}0.106^{* * *} \\
(0.0191)\end{array}$ \\
\hline$I N F L$ & $\begin{array}{c}-0.0911^{* * *} \\
(0.0115)\end{array}$ & $\begin{array}{c}0.0216^{* * *} \\
(0.00575)\end{array}$ & $\begin{array}{c}-0.0960 * * * \\
(0.0122)\end{array}$ & $\begin{array}{c}-0.0883 * * * \\
(0.0116)\end{array}$ \\
\hline$C A G D P$ & $\begin{array}{c}0.00359 * * \\
(0.00152)\end{array}$ & $\begin{array}{c}0.00268^{* * *} \\
(0.00101)\end{array}$ & $\begin{array}{c}0.0113 * * * \\
(0.00212)\end{array}$ & $\begin{array}{c}0.00334 * * \\
(0.00160)\end{array}$ \\
\hline POLITY2 & $\begin{array}{c}0.00928^{* * *} \\
(0.00184)\end{array}$ & $\begin{array}{l}0.00203 * \\
(0.00116)\end{array}$ & $\begin{array}{c}0.0113 * * * \\
(0.00235)\end{array}$ & $\begin{array}{c}0.00899 * * * \\
(0.00218)\end{array}$ \\
\hline $\log (P O P)$ & $\begin{array}{l}0.328 * * * \\
(0.0225)\end{array}$ & $\begin{array}{c}-0.0279 * * * \\
(0.00677)\end{array}$ & $\begin{array}{l}0.318^{* * *} \\
(0.0213)\end{array}$ & $\begin{array}{c}0.321 * * * \\
(0.0224)\end{array}$ \\
\hline Constant & $\begin{array}{c}-11.56^{* * * *} \\
(0.839) \\
\end{array}$ & $\begin{array}{c}0.784 * * * \\
(0.220) \\
\end{array}$ & $\begin{array}{c}-11.48 * * * \\
(1.071) \\
\end{array}$ & $\begin{array}{c}-16.39 * * * \\
(1.286) \\
\end{array}$ \\
\hline Observations-Countries & $368-92$ & $368-92$ & $368-92$ & $368-92$ \\
\hline Number of Instruments & 88 & 88 & 89 & 89 \\
\hline AR1 ( $P$-Value $)$ & 0.0015 & 0.0003 & 0.0004 & 0.0009 \\
\hline AR2 ( $P$-Value $)$ & 0.9069 & 0.6335 & 0.9526 & 0.9638 \\
\hline AR3 ( $P$-Value) & 0.2510 & 0.7204 & 0.2148 & 0.2345 \\
\hline OID ( $P$-Value $)$ & 0.4396 & 0.6164 & 0.7504 & 0.4670 \\
\hline
\end{tabular}

(Note) ${ }^{*} p$-value $<0.1 ;{ }^{* *} p$-value $<0.05 ;{ }^{* *} p$-value $<0.01$. Robust Standard Errors are in parenthesis. In the two-step system GMM estimations, the variables TAXREF, TRJURE, NATCST, FINDEV, POLITY2, CAGDP, and GDPC are considered endogenous. The other variables are considered exogenous. Time dummies are included in the regressions. 
test of first-order serial correlation $(\mathrm{AR}(1))$ in the error term; the Arellano-Bond test of no second-order autocorrelation $(\operatorname{AR}(2))$ in the error term; and the standard Sargan test of over-identifying restrictions (OID), which assesses the validity of the instruments used in the estimations. The test of the no third-order autocorrelation $(\operatorname{AR}(3))$ in the error term is also reported to show that there is no serial correlation at the third order, which might indicate that there is no omitted variable bias. As the number of instruments should be lower than the number of countries to ensure the tests are reliable (e.g., Roodman 2009), we also report the number of instruments used in the regressions. The outcomes of the tests show that the $p$-values of the statistics related to the $\mathrm{AR}(1)$ are lower than 0.01 , whereas those of the statistics related to the $\operatorname{AR}(2)$ and $\operatorname{AR}(3)$ are all higher than 0.01. Furthermore, the $p$-values related to the OID test are higher than 0.10 . Taken together, all these results confirm the suitability of the two-step system GMM estimator for the empirical exercise.

Turning to the estimates provided in column [1] of Table 2, we note that the effect of tax reform on trade openness (measured by OPENSW) is positive and statistically significant at the $1 \%$ level. A $1 \%$ increase in the index of tax reform is associated with a $0.5 \%$ increase in the level of trade openness. This result is similar in magnitude to the ones obtained in columns [1] and [2] of Table 1. Moreover, this result is confirmed in column [2] of the same table, that is, with the trade share as the measure of trade openness. However, the coefficient of the variable $O P E N$ reported in Table 2 amounts to 0.36 , which is slightly lower than the one of column [1].

Based on these two results, we can conclude that tax reform is positively associated with trade openness. This finding validates hypothesis 1 set out in section 2 . The estimates of the control variables have few differences in columns [1] and [2] of Table 2. In particular, column [1] shows that trade openness is positively driven by greater trade policy liberalization, higher real per capita income, lower amount of development aid flows, higher level of financial development, improvement in the current account balance, better institutional quality, a rise in the population size, and lower inflation rates. The results for the control variables in column [2] are also similar to those in column [1], although with different magnitudes of the coefficients. However, in column [2], the real per capita income exerts no significant effect (at the $10 \%$ level) on trade openness, though inflation exerts a positive effect on trade openness (here, trade share). This is different from the results in column [1] of the same table.

We now consider results in column [3] of Table 2. We find that the coefficient of both the TAXREF variable and the interaction (associated with the variable " $L D C^{*}[\log (T A X R E F)]^{\prime}$ ") are positive and statistically significant at the $1 \%$ level. The positive interaction term suggests that tax reform exerts a higher effect on trade openness in LDCs than in non-LDCs (countries of the full sample that are not classified as LDCs). These two results reveal that the magnitude of the net effect of tax reform on trade openness in LDCs is $0.979(=0.463+0.516)$, whereas 
it is 0.463 for non-LDCs. In other words, a $1 \%$ increase in the index of tax reform is associated with a $0.98 \%$ increase in the level of trade openness in LDCs and a $0.46 \%$ increase in the level of trade openness in non-LDCs. With few exceptions, the results of the control variables in column [3] of Table 2 are similar to those in column [1].

Let us now examine results in column [4] of Table 2. Note that these results aim to investigate the extent to which the effect of tax reform on trade openness (OPENSW) depends on countries' development level proxied by their real per capita income. Two coefficients are important to respond to this question: the coefficient of the variable $T A X R E F$ and the coefficient associated with the interaction variable $[\log (T A X R E F)]^{*}[\log (G D P C)]$. Specifically, we observe that TAXREF is positive and statistically significant at the $1 \%$ level, and the interaction term is negative and statistically significant at the $1 \%$ level. The combination of these two results suggests that there is a turning point of the real per capita income above which the effect of tax reform on trade openness becomes negative; otherwise, it is positive. This turning point amounts to 49618.6 US dollars [= exponential (0.0440/0.00608)]. This threshold of the real per capita income is far higher than the maximum value of countries' real per capita in the full sample (i.e., 14018.6 US dollars). Thus, irrespective of the development level of countries, tax reform always induces higher degree of trade openness. Further, the lower the development level, the higher is the magnitude of the positive effect of tax reform on trade openness. In other words, less advanced developing countries (including the poorest countries) experience a higher positive effect of tax reform on trade openness than relatively advanced developing countries do. Figure 2 confirms this finding by illustrating the developments of the marginal impact of tax reform on trade openness for different countries' development levels at the $95 \%$ confidence intervals. This marginal impact is always positive and statistically significant, but it decreases as the real per capita income increases. This signifies that less developed countries enjoy a higher positive effect of tax reform on trade openness than relatively advanced developing countries do.

\section{Conclusion}

This article examined the effect of tax reform on trade openness using an unbalanced panel dataset containing 92 developing countries, covering 1980 to 2014. The empirical analysis was conducted using an indicator of tax reform that captures the extent to which a developing country's tax structure converges toward developed countries' tax structure.

Over the full sample, the results suggest that tax reform is positively associated with trade openness. In addition, less advanced developing countries (such as poor countries) experience a higher positive effect of tax reform on trade openness than relatively advanced developing 
countries do. Overall, these findings suggest the tax (transition) reform in developing countries, including in poor countries, would increase their level of trade openness. The benefits of trade openness, including when accompanied by complementarity policies, have been well established in the literature (e.g., Chang et al. 2009). Therefore, measures that contribute to greater trade openness, while also mitigating its adverse effects on the economy, should be promoted. Governments in developing countries should pursue tax transition reforms, especially with the assistance of relevant international institutions, such as the IMF, the World Bank, and the United Nations. An avenue for future research could be to propose another indicator of tax "transition" reform, which would accurately reflect the governments' will to implement tax transition reform (de jure tax reform) and the extent of such tax reform. We note that this would be a challenging task.

\section{References}

Agénor, P.-R. (2004). "Does globalization hurt the poor?" International Economics and Economic Policy 1, no. 1, 21-51.

Agosin, R., Alvarez, R., and Bravo-Ortega, C. (2012). "Determinants of export diversification around the world: 1962-2000." The World Economy 35, no. 3, 295-315.

Ahmed, N. (2000). "Export Response to Trade Liberalization in Bangladesh: A Cointegration Analysis." Applied Economics 32, 1077-84.

Ancharaz, V. D. (2003). "Determinants of Trade Policy Reform in Sub-Saharan Africa." Journal of African Economies 12, no. 3, 417-443.

Andersson, M., and Johansson, S. (2010). "Human capital and the structure of regional export flows." Technology in Society 32, no. 3, 230-240.

Arellano, M., and Bond, S. (1991). "Some tests of specification for panel data: Monte Carlo evidence and an application to employment equations." Review of Economic Studies 58, 277-298.

Arellano, M., and Bover, O. (1995). "Another look at the instrumental variable estimation of error-components models." Journal of Econometrics 68, no. 1, 29-51.

Attila, G., Chambas, G., and Combes, J.-L. (2009). Official Development Assistance and Tax Transition, CERDI, Etudes et Documents, E 2009.01, University of Clermont I, CERDI-UMR CNRS, France.

Baltagi, B. H., Demetriades, P. O., and Law, S. H. (2009). "Financial development and openness: Evidence from panel data." Journal of Development Economics 89, no. 2, 285-296.

Baunsgaard, T., and Keen, M. (2010). "Tax Revenue and (or?) Trade Liberalization.” Journal of Public Economics 94, no. 9-10, 563-577.

Bertola, G., and Faini, R. (1991). "Import Demand and Non-Tariff Barriers: The Impact of Trade Liberalization.” Journal of Development Economics 34, no. 1-2, 269-86.

Birchler, K., and Michaelowa, K. (2016). "Making aid work for education in developing countries: an analysis of aid effectiveness for primary education coverage and quality." International Journal of 
Educational Development 48, 37-52.

Bleaney, M. (1999). "Trade Reform, Macroeconomic Performance and Export Growth in Ten Latin American Countries, 1979-95." Journal of International Trade and Economic Development 8, no. 1, 89-105.

Blundell, R., and Bond, S. (1998). "Initial Conditions and Moment Restrictions in Dynamic Panel Data Models." Journal of Econometrics 87, 115-143.

Borgatti, L. (2007). "Timing and sequencing of trade liberalization in the least-developed countries: Does foreign aid play a role?" Economia Internazionale LX, no. 1, 33-56.

Bray, J. R., and Curtis, J. T. (1957). "An ordination of the upland forest communities of Southern Wisconsin.” Ecological Monographies 27, 325-349.

Cagé, J., and Gadenne, L. (2018). "Tax revenues and the fiscal cost of trade liberalization, 1792-2006, 1792-2006." Explorations in Economic History 70, 1-24.

Chambas, G. (2005). "Afrique au sud du Sahara: quelle stratégie de transition fiscale?" Afrique Contemporaine no. 1, 133-163.

Chaney, T. (2005). Liquidity constrained exporters, University of Chicago Mimeo.

Chang, R., Kaltani, L., and Loayza, N. V. (2009). "Openness can be good for growth: The role of policy complementarities." Journal of Development Economics 90, no. 1, 33-49.

Collier, P. (2007). Growth strategies for Africa. A paper prepared for the Spence Commission on Economic Growth. Center for the Study of African Economies, Oxford University, United Kingdom.

Combes, J. L., and Saadi-Sedik, T. (2006). "How does trade openness influence budget deficits in developing countries?" The Journal of Development Studies 42, no. 8, 1401-1416.

Crivelli, E. (2016). "Trade liberalization and tax revenue in transition: an empirical analysis of the replacement strategy." Eurasian Economic Review 6, 1-25.

De Benedictis, L., and Tajoli, L. (2007). "Economic integration and similarity in trade structures." Empirica 34, 117-137.

De Benedictis, L., and Tajoli, L. (2008). Similarity in trade structures, integration and catching-up. 16, no. 2, 165-182.

Dollar, D., and Kraay, A. (2001). Trade, Growth and Poverty, mimeo. Development Research Group, The World Bank, Washington.

Dreher, A. (2006). "Does globalisation affect growth? Evidence from a new index of globalisation." Applied Economics 38, no. 10, 1091-1110.

Dreher, A., Nunnenkamp, P., and Thiele, R. (2008). "Does Aid for Education Educate Children? Evidence from Panel Data." World Bank Economic Review 22, no. 2, 291-314.

Driscoll, J. C., and Kraay, A. C. (1998). "Consistent Covariance Matrix Estimation with Spatially Dependent Panel Data." Review of Economics and Statistics 80, no. 4, 549-560.

Esfahani, H. S., and Squire, L. (2007). "Explaining Trade Policy in the Middle East and North Africa." The Quarterly Review of Economics and Finance 2007 46, no. 5, 660-684.

Fafchamps, M. (2009). "Human Capital, Exports, and Earnings." Economic Development and Cultural Change 58, no. 1, 111-141.

Farok, J., and Mudambi, S. (2008). "The Influence of Human Capital Investment on the Exports of Services 
and Goods: An Analysis of the Top 25 Services Outsourcing Countries.” Management International Review 48, no. 4, 433-445.

Finger, J. M., and Kreinin, M. E. (1979). "A measure of "export similarity" and its possible uses." Economic Journal 89, no. 356, 905-912.

Fujiwara, K. (2013). “A Win-Win-Win Tariff-Tax Reform under Imperfect Competition.” Review of International Economics 21, no. 5, 857-867.

Fukumoto, Y., and Kinugasa, T. (2017). "Age Structure and Trade Openness: An Empirical Investigation.” The World Economy 40, no. 6, 1247-1263.

Gnangnon, S. K., and Brun, J. F. (2017). "Impact of export upgrading on tax revenue in developing and high-income countries." Oxford Development Studies 45, no. 4, 542-561.

Gnangnon, S. K. (2019a). Effect of Development Aid on Tax Reform in Recipient-Countries: Does Trade Openness Matter? Accepted and forthcoming in the Journal of International Commerce, Economics, and Policy.

Gnangnon, S. K. (2019b). Tax Reform and Fiscal Space in Developing Countries. Accepted and forthcoming in the Eurasian Economic Review.

Goswami, N. (2013). "Determinants of Trade Development: Panel Evidence from South Asia." South Asia Economic Journal 14, no. 1, 17-33.

Gräbner, C., Heimberger, P., Kapeller, J., and Springholza, F. (2018). Measuring Economic Openness: A review of existing measures and empirical practices. ICAE Working Paper Series - No. 84 - August 2018. Institute for Comprehensive Analysis of the Economy, Johannes Kepler University Linz, Germany.

Guillaumont-Jeanneney, S., Kpodar, K., 2011. "Financial development and poverty reduction: can there be a benefit without a cost?" Journal of Development Studies 47, no. 1, 143-163.

Guttmann, S., and Richards, A. (2006). "Trade Openness: An Australian Perspective." Australian Economic Papers 45, no. 3, 188-203.

Gygli, S., Haelg, F., Potrafke, N., and Sturm, J.-E. (2019). "The KOF Globalisation Index - Revisited." Review of International Organizations, forthcoming. https://doi.org/10.1007/s11558-019-09344-2

Harrison, A. (2007) editor, Globalization and Poverty, National Bureau of Economic Research book, University of Chicago Press, 2007.

Harrison, A. (2018). "International trade or technology? Who is left behind and what to do about it." CDP Background Paper No. 45, ST/ESA/2018/CDP/45 Rev.1, United Nations, New York.

Hatzipanayotou, P., Michael, M. S., and Miller, S. M. (1994). "Win-Win Indirect Tax Reform: A Modest Proposal." Economics Letters 44, 147-51.

Hausmann, R., Hwang, J., and Rodrik, D. (2007). "What you export matters." Journal of Economic Growth $12,1-25$.

Hisali, E. (2012). "Trade policy reform and international trade tax revenue in Uganda." Economic Modelling 29, no. 6, 2144-2154.

Jansen, M., and Nordås, H. K. (2004) Institutions, trade policy and trade flows. WTO Staff Working Paper ERSD-2004-02, World Trade Organization, Geneva.

Ju, J., Y. Wu, Zeng L. (2010). "The Impact of Trade Liberalization on the Trade Balance in Developing 
Countries." IMF Staff Papers 57, no. 2, 427-49.

Karakosta, O., and Tsakiris, N. (2014). "Can tariff and tax reforms deliver welfare improvements under imperfect competition?" The Journal of International Trade \& Economic Development 23, no. 3, 315-328.

Keen, M. (2012). 'Taxation and development - again'. IMF Working Paper 12-220. Washington, DC: International Monetary Fund.

Keen, M., and Ligthart, J. E. (2002). "Coordinating Tariff Reduction and Domestic Tax Reform.” Journal of International Economics 56, 489-507.

Keen, M., and Ligthart, J. E. (2005). "Coordinating Tariff Reduction and Domestic Tax Reform under Imperfect Competition." Review of International Economics 13, 385-90.

Khattry, B., and Rao, J. M. (2002) "Fiscal Faux Pas?: An analysis of the revenue implications of trade liberalization." World Development 30, no. 8, 1431-1444.

Kim, D-H., Lin, S-C., and Suen, Y-B. (2010). "Are Financial Development and Trade Openness Complements or Substitutes?" Southern Economic Journal 6, no. 3, 827-845.

Kletzer, K., and Bardhan, P. (1987). "Credit markets and patterns of international Trade." Journal of Development Economics 27, 57-70.

Kotsadam, A., Østby, G., Rustad, S. A., Tollefsen, A. F., and Urdal, H. (2018). "Development aid and infant mortality: Micro-level evidence from Nigeria." World Development 105, 59-69.

Kreickemeier, U., and Raimondos-Møller, P. (2008). "Tariff-Tax Reforms and Market Access.” Journal of Development Economics 87, 85-91.

La Ferrara, E. (1996). "A Political Equilibrium Approach to Trade Liberalization in Developing Countries." Journal of International Trade and Economic Development 5, no. 3, 287-318.

Manova, K. (2005). "Credit Constraints in Trade: Financial Development and Export Composition." Harvard University mimeo.

Maruta, A. A. (2018). "Can aid for financial sector buy financial development?" Journal of Macroeconomics, Available online 20 November 2018. https://doi.org/10.1016/j.jmacro.2018.11.003

Milner, H. V., and Kubota K. (2005). "Why the Move to Free Trade? Democracy and Trade Policy in the Developing Countries." International Organization 59, no. 1, 107-143.

Moller, L. (2016). "Tax revenue implications of trade liberalization in low-income countries." WIDER Working Paper 2016/173, United Nations University World Institute for Development Economics Research (UNU-WIDER), Finland.

Munemo, J. (2011) "Foreign aid and export diversification in developing countries." The Journal of International Trade \& Economic Development 20, no. 3, 339-355.

Nickell, S. (1981). "Biases in Dynamic Models with Fixed Effects." Econometrica 49, no. 6, 1417-1426.

Pickbourn, L., and Ndikumana, L. (2016). "The impact of the sectoral allocation of foreign aid on gender inequality." Journal of International Development 28, 396-411.

Rajan, R., and Zingales, L. (1998). "Financial dependence and growth." American Economic Review 88, no. 3, 559-586.

Rodrik, D. (1995). "Political Economy of Trade Policy." In Handbook of International Economics, edited by Gene Grossman and Kenneth Rogoff, 1457-94+ Amsterdam, Netherlands: Elsevier Science Press. 
Rodrik, D. (1997). Has Globalization Gone Too Far? Washington, DC: Institute for International Economics.

Roodman, D. M. (2009). "A note on the theme of too many instruments." Oxford Bulletin of Economic and Statistics 71, no. 1, 135-158.

Sachs, J. D., and Warner, A. (1995). "Economic Reform and the Process of Global Integration." Brookings Papers on Economic Activity 1995, no. 1, 1-118.

Santos-Paulino, A. U. (2002a). "Trade Liberalisation and Export Performance in Selected Developing Countries." Journal of Development Studies 39, no. 1, 140-64.

Santos-Paulino, A. U. (2002b). "The Effects of Trade Liberalisation on Imports in Selected Developing Countries." World Development 30, no. 6, 959-74.

Santos-Paulino, A. U. (2004). "Trade Liberalisation and the Balance of Payments in Selected Developing Countries." Manchester School 71, no. 1, 100-18.

Santos-Paulino, A., and Thirlwall A. P. (2004). "The Impact of Trade Liberalisation on Exports, Imports, and the Balance of Payments of Developing Countries." Economic Journal 114, no. 1, F50-F72.

Squalli, J., and Wilson, K. (2011). "A New Measure of Trade Openness." The World Economy 34, no. $10,1745-1770$.

Svaleryd, H., and Vlachos J. (2002). "Markets for Risk and Openness to Trade: How are they Related?" Journal of International Economics 57, no. 2, 369-395.

Tanzi, V. (1992). "Structural factors and tax revenue in developing countries: a decade of evidence." In: Open Economies: Structural Adjustment and Agriculture, ed. by Goldin, I. and Winters, L. A. Cambridge University Press, chap. Structural factors and tax revenue in developing countries: a decade of evidence, pp. 267-281. (ISBN: 0521420563).

Tanzi, V., and Zee, H. H. (2000). "Tax policy for emerging markets: developing countries." National tax journal, 299-322.

Waglé, S. (2011). Coordinating Tax Reforms in the Poorest Countries: Can Lost Tariffs be Recouped? Policy Research Working Paper 5919. The World Bank, Washington, DC.

Wu, J., Li, S., and Samsell, D. (2012). "Why some countries trade more, some trade less, some trade almost nothing: The Effect of governance environment on trade flows." International Business Review 21, no. 2, 225-238.

Yeyati, E. L., Panizza U, and Stein, E (2007). "The cyclical nature of North-South FDI flows." Journal of International Money and Finance 26, 104-130.

Zee, H. H. (1996). "Empirics of cross-country tax revenue comparisons." World development 24, no. $10,1659-1671$. 
Appendix 1. Definition and source of variables

\begin{tabular}{|c|c|c|}
\hline Variables & Definition & Sources \\
\hline OPENSW & $\begin{array}{l}\text { Measure of trade openness suggested by Squalli and Wilson } \\
\text { (2011). It is calculated as the measure of trade openness (the } \\
\text { variable "OPEN" previously described) adjusted by the } \\
\text { proportion of a country's trade level relative to the average world } \\
\text { trade (see Wilson 2011, p1758). }\end{array}$ & $\begin{array}{l}\text { Authors' calculation based on } \\
\text { data extracted from the WDI }\end{array}$ \\
\hline OPEN & $\begin{array}{l}\text { Measure of trade openness (de facto trade openness). It is } \\
\text { calculated as the sum of exports and imports, in \% GDP }\end{array}$ & WDI \\
\hline TAXREF & $\begin{array}{l}\text { This is the index of tax (transition) reform. Higher values of } \\
\text { this indicator reflect greater extent of tax reform, while lower } \\
\text { values of this index indicate lower extent of tax reform. }\end{array}$ & $\begin{array}{l}\text { See the description } \\
\text { of this indicator in Section }\end{array}$ \\
\hline TRJURE & $\begin{array}{l}\text { Measure of De jure trade openness. It is in fact an indicator of } \\
\text { De Jure measure of trade globalization, which has been } \\
\text { calculated as a weighted index of trade regulations, trade taxes, } \\
\text { tariffs, and trade agreements developed (see Dreher } 2006 \text { and } \\
\text { Gygli et al. 2019). }\end{array}$ & $\begin{array}{l}\text { See the database and other } \\
\text { information online at: } \\
\text { https://www.kof.ethz.ch/en/forecasts- } \\
\text { and-indicators/indicators/kof-globalis } \\
\text { ation-index.html }\end{array}$ \\
\hline$G D P C$ & GDP per capita (constant 2010 US dollars) & WDI \\
\hline$N A T$ & $\begin{array}{l}\text { Net Aid Transfers (NAT), in Constant } 2015 \text { US dollars prices. } \\
\text { This is the net Official Development Assistance (ODA), from } \\
\text { which are subtracted principal payments are received on ODA } \\
\text { loans, interest received on such loans and debt relief. }\end{array}$ & $\begin{array}{l}N A T \text { data (in current prices) are } \\
\text { extracted from the database compiled } \\
\text { by David Roodman (see online: } \\
\text { http://davidroodman.com/data/) }\end{array}$ \\
\hline FINDEV & $\begin{array}{l}\text { Proxy for financial development. It is measured by the domestic } \\
\text { credit to private sector by banks ( } \% \text { of GDP). }\end{array}$ & WDI \\
\hline$C A G D P$ & Current account balance ( $\%$ of GDP) & WDI \\
\hline$I N F L$ & $\begin{array}{l}\text { The variable "INFL" has been calculated using the following } \\
\text { formula (e.g., Yeyati et al. 2007): } \\
I N F L=\operatorname{sign}(I N F L A T I O N) * \log (1+|I N F L A T I O N|) \text { (2), } \\
\text { where }|I N F L A T I O N| \text { refers to the absolute value of the annual } \\
\text { inflation rate (\%), denoted "INFLATION". } \\
\text { The annual inflation rate (\%) is based on Consumer Price Index } \\
\text {-CPI- (annual \%) where missing values has been replaced with } \\
\text { values of the GDP Deflator (annual \%). }\end{array}$ & $\begin{array}{l}\text { Authors' calculation based } \\
\text { on data from the WDI. }\end{array}$ \\
\hline $\begin{array}{l}\text { Proxy for the } \\
\text { Institutional } \\
\text { Quality } \\
\text { (POLITY2) }\end{array}$ & $\begin{array}{l}\text { Index extracted from the Polity IV Database (Marshall and } \\
\text { Jaggers 2009). It represents the degree of democracy based on } \\
\text { competitiveness of political participation, the openness and } \\
\text { competitiveness of executive recruitment and constraints on the } \\
\text { chief executive. Its values range between }-10 \text { and }+10 \text {, with lower } \\
\text { values reflecting autocratic regimes, and greater values indicating } \\
\text { democratic regimes. }\end{array}$ & $\begin{array}{c}\text { Polity IV Database } \\
\text { (Marshall and Jaggers, 2009) }\end{array}$ \\
\hline$P O P$ & Total Population & WDI \\
\hline
\end{tabular}


Appendix 2. Standard descriptive statistics on the variables used in the analysis

\begin{tabular}{cccccc}
\hline Variable & Observations & Mean & Standard deviation & Minimum & Maximum \\
\hline OPENSW & 581 & 0.001 & 0.003 & 0.000 & 0.038 \\
OPEN & 584 & 71.906 & 34.248 & 9.106 & 229.638 \\
TAXREF & 479 & 59.264 & 15.077 & 8.838 & 96.854 \\
TRJURE & 610 & 40.401 & 16.291 & 8.283 & 88.762 \\
GDPC & 599 & 2609.250 & 2632.648 & 151.102 & 14018.550 \\
NAT & 599 & $4.79 \mathrm{e}+08$ & $5.07 \mathrm{e}+08$ & 30000 & $3.83 \mathrm{e}+09$ \\
FINDEV & 573 & 24.634 & 21.079 & 0.335 & 146.545 \\
POLITY2 & 597 & 1.277 & 6.129 & -10.000 & 10.000 \\
CAGDP & 531 & -4.514 & 8.554 & -46.448 & 39.207 \\
$I N F L A T I O N$ & 602 & 74.106 & 447.608 & -3.016 & 6424.987 \\
POP & 629 & $4.25 \mathrm{e}+07$ & $1.57 \mathrm{e}+08$ & 297661.8 & $1.32 \mathrm{e}+09$ \\
\hline
\end{tabular}

Appendix 3. List of countries in the full sample

\begin{tabular}{|c|c|c|c|c|c|}
\hline \multicolumn{4}{|c|}{ Full Sample } & \multicolumn{2}{|l|}{ LDCs } \\
\hline Albania & $\begin{array}{c}\text { Dominican } \\
\text { Republic }\end{array}$ & Lebanon & Paraguay & Angola & Niger \\
\hline Algeria & Ecuador & Lesotho & Peru & Bangladesh & Rwanda \\
\hline Angola & El Salvador & Liberia & Philippines & Benin & Senegal \\
\hline Armenia & Fiji & Madagascar & Romania & Bhutan & Sierra Leone \\
\hline Azerbaijan & Gabon & Malawi & Rwanda & Burkina Faso & Tanzania \\
\hline Bangladesh & Gambia, The & Malaysia & Senegal & Burundi & Timor-Leste \\
\hline Benin & Georgia & Mali & Serbia & Cambodia & Uganda \\
\hline Bhutan & Ghana & Mauritania & Sierra Leone & Central African Republic & Zambia \\
\hline Bolivia & Guatemala & Mauritius & South Africa & Chad & \\
\hline Botswana & Guinea & Mexico & Sri Lanka & Congo, Dem. Rep. & \\
\hline Brazil & Guinea-Bissau & Moldova & Suriname & Gambia, The & \\
\hline Bulgaria & Guyana & Mongolia & Swaziland & Guinea & \\
\hline Burkina Faso & Haiti & Montenegro & Tajikistan & Guinea-Bissau & \\
\hline Burundi & Honduras & Morocco & Tanzania & Haiti & \\
\hline Cambodia & India & Mozambique & Thailand & Lao PDR & \\
\hline Cameroon & Indonesia & Namibia & Timor-Leste & Lesotho & \\
\hline Cape Verde & Iran, Islamic Rep. & Nepal & Tunisia & Liberia & \\
\hline Central African Republic & Jamaica & Nicaragua & Turkey & Madagascar & \\
\hline Chad & Jordan & Niger & Uganda & Malawi & \\
\hline China & Kazakhstan & Nigeria & Ukraine & Mali & \\
\hline Congo, Dem. Rep. & Kenya & Pakistan & Venezuela, RB & Mauritania & \\
\hline Congo, Rep. & Kyrgyz Republic & Panama & Zambia & Mozambique & \\
\hline Costa Rica & Lao PDR & Papua New Guinea & Zimbabwe & Nepal & \\
\hline
\end{tabular}

